The Embodied Object:

\title{
Recensions of the Dead on Roman Sarcophagi
}

Jaś Elsner

In J. M. Synge’s one-act play of 1903, The Shadow of the Glen, the action takes place in a 'cottage kitchen; turf fire on the right; a bed near it against the wall, with a body lying on it covered with a sheet. ${ }^{11}$ There is much gallows humour in this setting, of course, exacerbated by the dead body's sitting up and demanding a drop of whisky mid way through. The presence of the body is the play's controlling but disturbing conceit, and the dead man's being actually alive is its dramatic surprise. If there is an elephant in the room - or rather, we might say, a corpse in the cupboard - in the huge field of Roman funerary art, it is that the great majority of examples (funerary altars, reliefs, statues and so forth) are divorced from the dead body of the person they commemorate; but here sarcophagi are distinctive and different. For the sarcophagus uses the visual forms of consolatory celebration to frame the actual body of the deceased. ${ }^{2}$ Its rhetorics of eulogy are not merely performative but are directly existential, since its form and function are entirely dependent on the act of containing a corpse. For this reason, arguably the ultimate 'embodied object' in Roman antiquity is the sarcophagus. $^{3}$ 
As a type - produced in vast quantities and surviving to an extent that actually allows some forms of statistical and quantitative analysis as well as qualitative interpretation - the sarcophagus emulates, arguably even imitates, the shape of the body interred within. ${ }^{4}$ Embodiment is, in other words, scripted into the particular and peculiar formal nature of the sarcophagus as object - its long 'landscape' main face, its shorter sides, the need for a lid as a container of the body inside. This form - the oblong shape of the human body and roughly its size, miniaturized appropriately for the sarcophagi of children - is itself a strong marker of presence: the presence of the dead body contained within the coffin. ${ }^{6}$ Yet - and this is the key culturalhistorical datum - the relation of Roman sarcophagi to presence is complex and ambivalent. The different ancient contexts for the use and display of sarcophagi, ${ }^{7}$ from complete invisibility, ${ }^{8}$ via a limited openness to vision within tombs, ${ }^{9}$ and availability through placement in precincts and porticoes, ${ }^{10}$ to flamboyant public exhibition along the roadside, ${ }^{11}$ speak of a variable scale of presence and absence - the dead being doubly hidden when the sarcophagus itself is interred, but being implicitly present when the coffin is on public display. Traditions of display varied across the empire, with overt placement of large 'Attic' sarcophagi in public spaces probably the norm in the East, from Greece to Asia Minor and the Levant, ${ }^{12}$ and the range of 
variation around invisibility and display much greater in the West.

In addition to the visibility and accessibility of any given sarcophagus in relation to its embodiment of presence (a theme not irrelevant of course to the question of whether its decoration was made to be seen and for how long), the frequency of portraiture as a major element of sarcophagus decoration adds a further frisson to the question of embodiment. ${ }^{13}$ Now, despite the distinguished traditions of Roman portraiture, it is not entirely obvious what ought to count as a portrait in the imagery of Roman sarcophagi. In addition to the highly distinctive portrait features of such figures as the main protagonists in plates 3, 4, 8, 11 and 12 in this article, there are a number of much more generic figures (such as the reclining child in plate 10 or the couple in a medallion in plate 2) which may certainly refer to the person or persons interred within the casket. I am broadly going to take an inclusivist position that allows any figure which ancient viewers might have taken to be a possible portrait to be counted. Moreover the range of possible portraiture is very wide - extending from three-dimensional figures reclining on the lids of caskets (effectively statues) to full body portraits of relief figures presented as statues in the centre or on the edges of the chest, especially in strigillated examples, ${ }^{14}$ or reclining on a couch (as in plate 10) or incorporated into the action of a narrative scene, including into 
the body of a mythical hero or heroine. ${ }^{15}$ But it also includes busts, especially those framed in a medallion in the honorific medium of the imago clipeata. ${ }^{16}$ I shall touch on all these principal forms of portraiture on sarcophagi before turning to my main focus, on three-dimensional reclining statues carved on lids in relation to their play with the thematic of embodiment, presence and absence. ${ }^{17}$

\section{SARCOPHAGUS-PORTRAITURE: ENLIVENED FACES}

The most common form of portraiture on sarcophagi, significantly under-discussed in the literature, is the medallion or tondo with an actual or ideal portrait inside - sometimes of one person of either gender, sometimes of a married couple, occasionally of two people of the same gender (plate 1$).{ }^{18} \mathrm{~A}$ fine example from Pisa, for instance, from the mid-third century CE, has a couple in the central medallion both with finished portrait heads (now rather abraded). The wife places her left arm over her husband's left shoulder, while the tondo's rim has a zodiac carved into it. Below the roundel is a rather damaged scene of ploughing, with reclining personifications of the earth and the sea to the left and right respectively. Around the couple stand the four seasons, two on each side, nude, male and winged, who originally held the cornucopiae, or baskets full of fruit and flowers, that are alongside their heads but whose bottoms and the hands holding them have now been broken off. ${ }^{19}$ 
The medallion may be presented as a frame around the pair, as in this case, sometimes as a wreath and occasionally as a conch shell. Most frequently the tondo portrait is placed as the central feature of the main casket, ${ }^{20}$ but more rarely it may appear on the lid. ${ }^{21}$ Such portraits mark a kind of presence, articulated through the central visual claim on the chest of a casket or its lid, through the medallion on which the typical decorative focalization of sarcophagi converges. ${ }^{22}$ In this case the imagery casts the couple in an idyll of passing time (symbolized by the seasons, the zodiac and the annual cycle of ploughing) which is marked by fecundity (in the cornucopiae or baskets) and the support of earth and sea. But at the same time the tondo is framed and hence separate from the imagery around it - explicitly excluded, perhaps we should say secluded, from the main visual action of the decoration. Such medallion portraits are celebrated by their surrounding imagery perhaps, but are always differentiated from it. ${ }^{23}$ The medallion portrait, although it represents the dead as alive, nevertheless marks a kind of ideal frozen absence, itself emulating the separation of tondo from visual field, implying perhaps a memory, much as the coffin itself signals the absence of the deceased despite and because of the presence of his or her physical remains.

The most widely discussed form of portraiture in sarcophagi is found in narrative or 'genre' reliefs where portrait heads of the deceased were given to figures within the imagery 
carved on the base or lid. Heroes and deities in the so-called mythological sarcophagi and actors in all kinds of scenes of ‘daily life’ (hunting, battles, dining, marriages, leave-taking and so forth) may be supplied with portraits, ${ }^{24}$ often intriguingly left unfinished when the casket was interred. ${ }^{25}$ Clearly the incorporation of the physical features of the deceased into grand narratives, both of life-activities such as hunting or war and with mythological subjects, has encomiastic potential as a visual eulogy - in ways parallel to, say, the frieze of Trajan's column and other imperial reliefs. ${ }^{26}$ Some of the choices seem disconcerting to modern sensibilities - such as the loving couples depicted as the adulterous Venus and Mars or as Achilles killing Penthesilea- but such issues are probably our problem. We may argue that, as a visual and material instantiation of the rhetorical structures of ancient Roman mourning, ${ }^{27}$ sarcophagi use portraiture to supply panegyric through images - amplifying and elaborating the memory of the deceased through narrative (especially mythological) contexts and adducing such devices as personification, as well as a stress on deeds and accomplishments, which were fundamental to the ancient rhetorical handbooks' prescriptions for monody, consolations and funerary eulogies. ${ }^{28}$ But just as verbal rhetoric is a double-edged sword, with the risk of emptiness in that its subject may fail to live up to the virtues extolled, so the rhetoric of embodiment in all forms of portraiture on sarcophagi offers 
absence as much as presence, and potentially the sign of the emptiness of all consolation (visual and literary) in the face of the rupture of death. While Christian-themed sarcophagi appear to have abandoned lids with with three-dimensional sculptures of the deceased reclining as at a banquet or in sleep (known as kline-lids, which are a definite genre in both eastern and Roman sarcophagi as well as their Etruscan predecessors, including funerary urns), both portraits within tondi and idealized portraits on frieze sarcophagi are frequent, implying some continuity in the visual rhetoric of presence and absence, despite the fundamental transformations of attitudes towards death and salvation with the institutional establishment of the new religion. $^{29}$

Plate 2, for instance, a fine mid-fourth century CE example from Arles, shows a couple in the central conch-shaped tondo (in much the same posture and attitude as the pagan couple a century earlier in plate 1) within a two-tier visual field with imagery from the Old and New Testaments. ${ }^{30}$ Below the medallion is the scene of Jonah and the whale. Here the basic schema of the double portrait reflecting mourning over a married couple is lifted from the surrounding imagery of natural tranquillity, normal in a pagan sarcophagus, ${ }^{31}$ as in the seasonal and ploughing imagery of plate 1 , and placed in context of scripturally guaranteed salvific felicity, underpinned by Christian mythology. 


\section{STATUARY IN THE ROUND: AND EMBODIMENTS OF}

THE DEAD

My focus here, however, will be statuary in the round on lids. One striking form of lid, in both eastern and Roman sarcophagi, is the sculpted three-dimensional kline, where a single individual or a couple reclines on a couch. These are relatively rare, ${ }^{32}$ but include some significant examples. Since so many sarcophagi have lost their original lids, it may be that the phenomenon was much more frequent than it seems - it is certainly more common in eastern than in Roman examples, but I will here be mainly concentrating on material made in Rome or at least used there in antiquity. ${ }^{33}$ As a type they effectively conflate the sarcophagus base with a relatively common form of funerary monument, which is similar to but needs differentiating from sarcophagus lids, namely the kline monument with the deceased shown reclining or in sleep. ${ }^{34}$ The difference between a kline monument and a kline lid is that the monument uses a certain statue type to reflect upon the absence of a deceased person while the kline lid not only juxtaposes portrait with corpse but also performs a kind of homology between the lying body inside the coffin and the reclining body above it. That homology is particularly interesting because all kline lids show the figure or figures with feet at left and head at right. Now we cannot know that this was always the way that corpses were laid 
inside coffins, but a certain amount of observational evidence seems to imply this. For instance, the famous sarcophagus of Crepereia Tryphaena, discovered in Rome in 1889 and famous because of the beautiful doll that was found inside alongside the skeleton, ${ }^{35}$ certainly had the body laid out with feet at the left end and head at the right; the front of the piece is strigillated and the left end shows a couple, perhaps the parents, mourning over the deceased or dying girl, who reclines on a couch in the same orientation (from left to right).

The kline lid typically depicts one person of either gender, or a married couple, reclining; the figures may be relatively upright and engaged in some activity such as performing music or holding a scroll (perhaps reading, as in plate 5$),{ }^{36}$ or they may be lying down in sleep or death (as in plate 7 and plate 8 ). ${ }^{37}$ Here we have a motif of three-dimensional commemorative statuary that uses the sarcophagus itself as a form of statue base. ${ }^{38}$ Again this is not abnormal - triumphal arches and the historiated columns (all complex objects with relief sculpture and architectural features, like the sarcophagi themselves) ${ }^{39}$ certainly functioned as statue bases for three dimensional honorific and commemorative images throughout the Roman world. Occasionally such historiated statue bases were funerary - a classic instance is Trajan's Column, whose pedestal was also the burial site of the emperor's ashes. 
Kline lid statues are typically lifesize or slightly smaller: they appear to embody the tangible presence of the dead in the vicinity of their earthly remains. Yet the gap between the dead as they once were or as they are ideally imagined to have been, depicted in the heyday of life in their statues, and their current condition as rotting corpses or bones within the box beneath the image, could hardly be more powerful. Arguably the very hiddenness of the remains makes their difference from the norms of the living that much greater. So even as mimetic statuary in the round may offer the promise of presence, the content of the coffins firmly denies that presence (at any rate in the lifelike form made tangible by the statues) and implies the absence of the deceased, on whom the whole panoply of images and inscriptions appears to focus, from the lives of viewers and mourners.

These kinds of sarcophagi offer very interesting commentaries on the issue of embodiment in their play not only on the dead body inside the casket but also on the differences between relief decoration on the base and three-dimensional figuration on the lid. Take some impressive examples - such as the so-called Balbinus sarcophagus of about $240 \mathrm{CE}$ from the Praetextatus catacomb (plate 3), ${ }^{40}$ or the columnar sarcophagus made in the late third or early fourth century CE that appears to have been used for Aurelius Theodorus by his wife, Varia Octabiana, in the late fourth or early fifth century CE and is in 
the Villa Ada in Rome. ${ }^{41}$ In both these cases, the reclining couple on the lid not only throws into three-dimensions the figures portrayed in the 'biographical' imagery of the base, but also adds a further scene of reclining together to the narrative cycle (in life? or in the afterlife?). In these examples, the oncein-a-lifetime moment of the marriage of two particular people depicted in the dextrarum iunctio on the trough (in the centre of the Theodorus casket and to the right of the Balbinus sarcophagus) is not only extended into the eternity of an indefinite lying together that could be for all time and anytime, but is also expanded into three dimensions. Yet that threedimensionality - while implying all times rather than just one particular time - is in conflict with the putrefaction inside these caskets. My point is that the use of two- and three-dimensional imagery is a thoughtful commentary on the performance of monumentalizing and commemorating and their relations to death, which speaks to the ambivalence of these coffins about the embodiment that is central to their nature.

In a child lenos (or tub-shaped sarcophagus) of about 280 $\mathrm{CE}$ in the Vatican (plate 4), ${ }^{42}$ the lid shows a reclining funerary statue of a boy in tunic and pallium, ${ }^{43}$ holding papyrus scrolls both open and rolled, with a small dog. Beneath, on the base, he is enthroned bare-chested in a pallium, seated frontally in the centre of the field and framed in cloth. His left hand grasps an open scroll, just as it does in the kline image above, while with 
his right hand he gestures to the figure beside him who is writing on a wax diptych, like the 'book' made up of such diptychs on the couch next to him on the lid. Surrounding him on the base are nine male youths, all standing and bearing attributes of the Muses. ${ }^{44}$ The boy is shown as a philosopher amidst the nine Muses, all of whom are represented as male putti like himself. Obviously, the themes of education and paideia, or cultural formation, are powerful here and link base with lid. They form a strong consolatory and eulogistic category for deceased youths. But while the boy reclines in solitude on the lid, by contrast with his seated accompaniment by Musethemed acolytes on the base, a sleeping putto appears to the far left of the lid. The putto is nude where the statue on the lid is clothed and most of the figures on the base half-draped; it sleeps where all the other figures are awake. One might hazard that it undermines the memorializing fantasy of paideia and makebelieve education (where even the Muses change gender to appear as boys, or boys dress up as if they were Muses), ${ }^{45}$ with the image of sleep and nudity gesturing to death, and the potential implication of a further unrobing of flesh leading directly to the decomposed body within the casket itself. The theoretics of play-acting, of children as adults or deities, of education in its many guises (literary, musical, dramatic) relate to both the process of formation of the child into a man and to the ambivalence of the 'might-have-been' of 
this educational imaginaire beside the actuality of putrefaction inside the coffin. In this example the kline portrait sits atop a make-believe fantasy of what the subject's education would have been had he lived (and lived up to his parents' hopes). This kind of aspirational CV of what might have been stands one step beyond the visual performance of biographic 'actualities' in such objects as the Balbinus or Theodorus sarcophagi.

A number of grand mythological caskets preserve their kline lids. In these cases the base performs a slightly different function from the 'biographic' and 'educational' imagery we have been exploring, since it grounds the deceased in a series of mythological claims that may signal culturally prestigious virtues, ${ }^{46}$ or even religious intimations, but may also be still more significantly marked by rhetorically amplifying elements of make-believe. One might cite cases where mythological imagery seems hardly to relate to the iconography of the lid except as a kind of elevating elaboration of the deceased's significance. For instance, the great Achilles in Scyros sarcophagus, found in a tomb in Rome in 1582 and now in the Capitoline Museum, is of Attic manufacture from the mid third century CE but was brought to Rome in antiquity and finished with Roman portrait heads for the kline couple. ${ }^{47}$ Likewise a couple of late third or early fourth century CE Meleager sarcophagi - the most famous was found in Tivoli, is in the Palazzo Conservatori and was discussed by Riegl in his Late 
Roman Art Industry of $1901^{48}$ - show the scene of the

Calydonian Boar on the base with a reclining kline couple above (plate 5). ${ }^{49}$ The Conservatori lid, with unfinished heads, has the woman playing an instrument and the man holding an unrolled scroll (as if reading or singing) with two putti, of which one holds a theatrical mask and the other leans on a column with a dog beside him, his ear cocked as if listening. In this case, the Meleager narrative, and the two scenes of hunting on the smaller sides, may be seen as the epic performance of the husband's song or poem to his wife's musical accompaniment. Another relatively simple case is the great sarcophagus with Dionysus and the seasons from the second half of the third century CE now in Jerusalem - the only surviving Seasons sarcophagus with a kline lid. ${ }^{50}$ There the base, with its imagery of Dionysiac bliss and the seasonal cycle of life, ${ }^{51}$ appears as a fitting frame for the lives of the reclining couple on the lid.

But there are a number of more pointed visual parallels in some mythological imagery between lid and base. Take the Phaethon sarcophagus of $c .300$ CE now in the Villa Borghese (plate 6), where the reclining couple of the lid are emulated by three reclining personifications, male and female, in relief on the base - the two in the trough's centre semi-naked, the one to the right fully clothed and accompanied by putti (as are the couple on the lid). ${ }^{52}$ The clothed and semi-clothed placidity of the range of reclining figures (relief and three-dimensional) is in contrast 
with the magnificent and angular dynamism of the two falling male nudes (Phaethon himself and perhaps his boy charioteer or attendant) at the dramatic centre of the casket's visual action. In this case, while the mythological subject is of course tragic and reflects powerfully on the theme of death, ${ }^{53}$ the relationship of the three personifications to the kline statues - two of them lying in the same orientation with their heads to the right and the third lying the other way around - offers a paranarrative alongside the mythological story. Both the lying figures in the round and the lying figures in relief comment - beyond the mythical subject matter - on the actual lying body or bodies inside the casket, but in interrelated and perhaps playfully different ways. The personifications are not portraits like the lid figures, but they are idealized types. The game of numbers, two on the lid and three on the base, itself comments on the issue of how many are interred within - one body, two (a husband and wife) or several corpses over several generations in a given family. ${ }^{54}$ In a now lost Endymion sarcophagus from the Palazzo Colonna, whose inscription, lid and iconography are fortunately preserved in drawings (plate 7), ${ }^{55}$ the clothed sleeping portrait of Andia Melissa, for whom the monument was set up by her husband, L. Valerius Victor, occupied the lid in three-dimensions, with a sleeping dog by her feet. ${ }^{56}$ On the base was the theme of Selene coming upon the sleeping Endymion, with cupids pulling off his robe to reveal his torso and genitals, and a seated dog to the 
right. The nude male relief and the clothed female statue lie in the same orientation, their dogs differently placed (by Endymion's head and Andia Melissa’s legs). There is obviously a play here on issues of gender and on the relations between sleep and death as well as a reflection on the lying corpse within the casket, which is normal in this kind of imagery.

Most remarkable in the surviving mythological group is a late third or early fourth century CE child's sarcophagus now in the Capitoline Museum with a sleeping or dead boy in a toga on the lid (plate 8). ${ }^{57}$ The base has Prometheus in the centre creating man, who is then placed like a miniature statue on a pedestal and is endowed by Minerva with psyche in the form of a butterfly, while two of the Fates spin his lifespan and write his horoscope onto a globe. ${ }^{58}$ There is a potent ambiguity as to whether this is the creation of all mankind or of the specific youth who is buried in the casket and portrayed on its lid, as implied by the spindle and horoscope of the Fates. To the left are reclining semi-nude personifications of the sea and the earth, with Cupid and Psyche, and beyond them on the corner to the left, the smithy of Vulcan from which Prometheus stole fire. On the left end, most strikingly, is an image of Adam and Eve, as a kind of Christian or Jewish creation comparandum with the Prometheus myth (plate 9). ${ }^{59}$ On the right of the main base is a scene of lamentation for the deceased boy, with a female figure of mourning next to Minerva; the child himself lies dead and 
naked at the lower right with a putto holding an inverted torch at his feet and another of the Fates reading the book of his life. If Prometheus is to be seen as making this particular child, represented three times as a nude boy, and the whole subject framed by the Fates, then the story being read from the Fate's scroll may be said to be visually enacted by the process of moulding, enlivening the statue and mourning the prone figure. To the right Mercury leads away the boy's soul - personified as Psyche with butterfly wings. On the right end is the scene of Hercules rescuing Prometheus from being chained to a cliff in the Caucasus.

This is a remarkable object, with its repeated iconography of Psyche, its Prometheus theme, its cosmological placement of a personal death within two creation narratives of man as well as an elemental cosmology of earth and sea, with the chariots of the sun and the moon in the upper parts of the visual field left and right, its narrative of the Fates and its exceptional syncretism of Christian-Jewish with traditional pagan mythology. One might even read the whole cycle from the left end to the right in Christian salvific terms, allegorized through classical myth to show the Fall (both Adam and Eve and the theft of fire) via the creation of man and the human experience of life and death to salvation, where Hercules rescues Prometheus from his purgatorial sufferings. ${ }^{60}$ But alongside this hyper-sophisticated meditation on both the particularity and the 
general implications of life and death, the sarcophagus offers a paranarrative of three forms of reclining figure - half-nude personifications (male and female) to the left and the nude boy to the right, both in relief, as well as the clothed figure, sleeping or dead, in the round on the lid. Here three sets of reclining figures with different valences (commemorative portrait, generalized personifications, the body of this deceased child), different levels of three-dimensionality and different states of dress, are all implicitly set against the boy's skeleton inside the casket, soon itself to be undressed of all flesh. That series of visual recessions, mapping onto the movement of threedimensions to two dimensions to hidden away inside the coffin, itself parallels the sarcophagus' play with figures in human form creating human beings that are represented as works of art, notably the nude statue on his pedestal.

In the central group Prometheus is making man (as a nude boy), in an emulation of the way an artist makes a statue holding the figure in his left hand and holding an engraving tool, perhaps a stylus, in his right. Minerva unites the bodily form of man (now represented as a nude boy on a statue base, as a lifeless but lifelike work of art) with life-giving spirit in butterfly form. It is the separation of that spirit from the bodily form (potently lying as the statue on the lid lies and in the same orientation) which is dramatized on the right, as Hermes leads the soul away. The statue theme - reinforced by the struts that 
join its hands to its hips (struts possessed by no other figure on this sarcophagus and so deliberately made to refer to the 'workof-artness' of the statue-as-man $)^{61}$ - shifts the myth's narrative, which has man moulded in clay, to something much more selfreferential in relation to the art of a marble sarcophagus, with man moulded as marble statue, complete with struts which deny the possibility of the figure being imagined as bronze or clay. The boy as statue, which is also the first form of man, plays brilliantly on the ambivalence of general and particular not only in sarcophagi but in all consolatory rhetoric about the dead, while at the same time relating the theme of death to that of art and creation. The column on which the globe stands, where the horoscope is being written (engraved with a stylus as Prometheus engraves his man-statue), is itself a visual counterpoint to the statue base of man, both effectively works of art and the result of creative artistry by forces beyond human ken or control.

The Capitoline Prometheus casket is not the only one that makes so sophisticated a play on reclining figures. In a lionhead lenos, perhaps from Ostia and now in Stuttgart, dated to the Severan period, the clothed child on the kline lid, who has unfortunately lost his portrait head, reclines next to a male putto (plate 10). ${ }^{62}$ Beneath, on the reliefs of the base, he reclines again - his shoulder bared - on his deathbed, eyes closed and lamented by female figures with Mercury at his feet, presumably 
about to lead his soul to the underworld. No one in the literature has yet suggested that the figure on the lid may have been female, but the slight swelling of the right breast does make me wonder. One of the oddities about the boy reclining in death on the base is that he does appear to be in female dress, with loose fitting chiton and palla that cover only the left shoulder and lower body, ${ }^{63}$ an example of cross-dressing that is in fact not uncommon on Roman sarcophagi, ${ }^{64}$ and is perhaps especially associated with the imagery on child coffins, potentially when social gender was not entirely settled. ${ }^{65}$ Beneath the lion's head to the left are the nude twins Romulus and Remus with the Wolf, while beneath the lion's head on the right is a reclining nude youth. On the curve to the right two women wash the baby boy, while a woman (perhaps his mother) sits in what may be mourning. On the curve to the left, the boy stands in a toga holding a scroll, with his seated teacher behind him, also holding a scroll. On a column to the far left is a helmeted bust, perhaps of Mars and perhaps related to the image of the twins. Here we have a 'biographical' narrative of the child's life from early washing (on the right) via the process of paideia (on the left) to premature death, or we may say that the death scene is framed by the major events of his life (birth and education). This is visually presented as a process from nudity in the washing scene, via dress in the education scene, to the dress but with bared shoulder in the death scene, but it plays against the 
naked child figures beneath the lions' heads, of which the left hand group of the twins is certainly mythological and ties the whole programme into a grand frame of Rome’s foundation and heritage.

In this case, that relief narrative is cut across by the visual paranarrative of reclining portrait in the round and reclining reliefs - alive and in death, nude and dressed - on the trough, which themselves take the object's implications directly back to the body inside it. The implication of sexual- or genderambiguity, or cross-dressing, in the reclining figure of the base and potentially in that of the lid of course resonates with the ultimate absence of gender in the bones that will be all that remains inside the coffin. ${ }^{66}$ The recession of reclining figures in different dimensions itself plays against the imagery of 'real' figures and works of art (the bust of Mars on its column) on the base, and against the recession of nude boys from the threedimensional putto on the lid to the various naked figures in relief below. As in the Prometheus sarcophagus from the Capitoline, all this frames and resonates with the skeleton in the casket around which this imagery is constructed. This piece is one of a rich group of sarcophagi with reliefs showing explicit imagery of death on a bed - both in the so-called 'vita privata' genre $^{67}$ and in mythology (notably the Meleager cycle and in a unique image of Patroclus). ${ }^{68}$ 
I will end on one subcategory of the kline sarcophagus, which has hardly been discussed. Like so many portrait heads in the relief decoration of sarcophagi, a number of kline lids - for all the exquisite finish of the rest of the casket - have unfinished portrait heads. ${ }^{69}$ An outstanding example, originally found in a grave near Tivoli, is the great Meleager sarcophagus in the Museo Conservatori, discussed earlier, where the heads of both members of the reclining couple are roughed out in a kind of blank (plate 5).$^{70}$ Also from near Rome, discovered in the Vigna Sassi, is the Tetrarchic child sarcophagus with Seasons, now in the garden of the Hammond Castle Museum in Gloucester, Massachusetts, whose single reclining figure with unfinished head caresses a small dog, ${ }^{71}$ and the Phaethon sarcophagus in the Villa Borghese (plate 6). Similar instances from the east include at least the head of the woman from an Attic Achilles sarcophagus in Tyre (where the man's head no longer survives), ${ }^{72}$ the two heads of a fine sarcophagus with drunken cupids on the front base and sides, and griffins at the back found in Tyre and now in the Beirut museum (on the basis of archaeological context, these two examples from Tyre were certainly on public display in antiquity), ${ }^{73}$ the fine coffin of Aurelia Botaine Demetria, from the west necropolis of Perge, now in the Antalya Museum (where the woman's head is finished and the man's is left blank, plate 11$),{ }^{74}$ a number of column sarcophagi made of marble originally from 
Dokimeion, ${ }^{75}$ both heads on the magnificent late second- or early third-century Attic Achilles sarcophagus now in the Getty Museum, ${ }^{76}$ both heads on the fine Amazon sarcophagus in Thessalonike, ${ }^{77}$ both heads on an impressive rape of Persephone casket found in Ashkelon in Palestine, ${ }^{78}$ and the heads on some fine examples from Cyrene which appear not to be properly published. ${ }^{79}$ There is also the intriguing example of a Severan kline lid with a couple, probably made in Italy and surviving without a base, purchased by the Metropolitan Museum in New York in 1993 and formerly in a private collection in England (plate 12) ${ }^{80}$ Here the male has a fine finished portrait head but his wife does not. It may be this is the result of 'restoration' of the object at some time after antiquity - photographs from before 1990 show that the female head was removable, although it certainly preceded the object's arrival at the Metropolitan Museum. ${ }^{81}$

Now the traditional argument that these heads are somehow unfinished - left for the portrait of the deceased, which at the last moment never got carved into the final coffin seems to me to be too easy. ${ }^{82}$ There are simply too many of such 'unfinished heads' across all genres of sarcophagus portraiture, and virtually none in any other genre of funerary portraiture. ${ }^{83}$ The phenomenon of the blank portrait is almost entirely restricted to sarcophagi, where it is frequent. ${ }^{84}$ Even if at some early stage in the production of this type of monument, portrait 
features were left unfinished due to the need for speedy burial after an untimely death, by the time thousands of sarcophagi were being produced, ${ }^{85}$ the unfinished head - especially in the context of a magnificently finished casket (such as the Portonaccio battle sarcophagus, ${ }^{86}$ plate 13 , for instance, among frieze sarcophagi, or the Conservatori Meleager among kline types, plate 5) - is a choice. ${ }^{87}$ Moreover, the blank head is a replicative choice within the larger thematic - very common indeed in Roman art - of replicated portrait heads in many genres of sculpture (both three-dimensional and relief). These include portraits of elite figures such as emperors and empresses but also private individuals. ${ }^{88}$ But where normative replication in portraiture yields a positive identity and the affirmation of distinctive personality, the replication of blankness across numerous individuals affirms a bottom line beyond living identity - a shared commonality of the absence of personality in the identikit space of death. In the case of our three-dimensional kline portraits, the choice is to elide a specific characterization of the deceased as they were in life in favour of a signalled facial absence.

The animation of a body in living action but with a face without distinguishing features plays against the body within the casket as it rots and ultimately becomes a skeleton. In a sense the unfinished head advertises the state of decomposition within the coffin itself but does so in the decorative panegyric of the 
visual imagery on its exterior. There is a further difference specific to the kline sarcophagi between shaped but blank heads (like those on the Conservatori Meleager or the New York lid, plate 5 and plate 12) and the great uncarved blocks in place of heads that we find on a number of Asian and Attic examples (such as the sarcophagus from Perge, plate 11). All the blank heads in sarcophagus reliefs - both within mythological or narrative action (as in the Portonaccio casket, plate 13) or as images within a tondo - belong to the shaped category, evoking a might-be-but-not-quite-there being as in the Conservatori Meleager lid (plate 5). But the kline cases of uncarved blocks (e.g. plate 11) - shocking denials of the exemplary artistry and expense of the rest of the object - stand as a brash insistence on the implausibility, arguably the impossibility, of accessing death in the imitative artistic medium of fine sculptural statuary. In one instance, from Konya, what was once a large unshaped blocked head looks as if it was subsequently carved into a male portrait in the 240s or 250s CE, which remains unfinished and roughly blocked out at the back. ${ }^{89}$

The shaped but blank heads, in being pseudo-animate, point to a space between life and death, or one which is neither alive nor dead, perhaps to a space of the 'shade' in death mimicking the activities of its former life. The blank head is a way of naming the representation of the no-longer living as being of a different order to that of living persons, and yet of 
celebrating their no-longer livingness in the midst of a visual frame of eulogistic consolation. The block in place of the head, by contrast, is a powerful formal challenge to eulogistic visual commemoration - a material announcement there are spaces where the encomiastic rhetorics of visual memorialization simply cannot operate. One aspect that the kline sarcophagi add to the semiotic discourses of Roman funerary art is a material and monumental differentiation between the forms and handling of different kinds of unfinish in the treatment of blank 'portraiture'. It is striking that unfinished heads are a genre above all in sarcophagi among funerary monuments - that is, they have a cultural resonance with the fact that the dead body is actually contained inside the commemorative visual encomium. This relation to the interred body, a kind of visual commentary, goes alongside the commentary offered by the reclining form, which we have been exploring. There is something profoundly strange in the three-dimensional figure with an unfinished head conducting him or herself as if in the world - reading from a scroll, playing a musical instrument, stroking a dog - occupying the same real space in the world as the dead person would have done. Perhaps that strangeness is one of Roman culture's more powerful reflections on the mystery of death.

In this article I have been exploring some aspects of what we might call the visual response of sarcophagi as a medium of art to their special existential status. From a viewer-centred 
perspective, it is a case of what we see and what we know. What we see is the monument itself and its proliferation of imagery, often quite savvy and quite sophisticated, sometimes witty, even when quite simple. What we know- like the audience of Synge's Shadow of the Glen - is that there is a body in the box. We do not see that body at any time, unlike Synge's audience, when 'the sheet is drawn slowly down and Dan Burke looks out,' saying 'with a hoarse voice', 'Don’t be afeard, stranger; a man that's dead can do no hurt. ${ }^{90}$ But the knowledge of the corpse's presence in the casket creates the preconditions of our response and indeed of the object's nature. The body's shape determines the oblong shape of the casket and the 'landscape' field of the principal decorative space of its base; the need to contain the corpse determines the trough-and-lid form of what is essentially an ornamented coffin. I have been arguing that in different ways much of the visual rhetoric of sarcophagi - which is to say not only their decoration but also the knowing relationship of that decoration to the body inside and the viewer outside - plays on and between what we see and what we know but do not see.

\section{Notes}

I am especially grateful to all my friends at the New Antiquity conference that took place at Stanford in 2015, where this paper was first delivered (and to Jen Trimble for organizing), as well as to Zahra Newby for inviting me to give a revised version in Warwick in 2016 and 
to John Patterson for hosting a finished revision at the Cambridge Philological Society in February 2018. The text was much improved by the editors alongside Sam Bibby at Art History, and by my good friends Mont Allen, Janet Huskinson and Katharina Meinecke. Mont has also proved a hero in helping me with photographs.

${ }^{1}$ J. M. Synge, Plays, Poems and Prose, London, 1958, 3 (opening stage directions).

${ }^{2}$ For recent reflections on embodiment in the context of Greek and Roman funerary art, see the papers by Patrick Crowley and Michael Squire in this issue, the former with some discussion of sarcophagi.

${ }^{3}$ General accounts of sarcophagi include G. Koch and H. Sichtermann, Römische Sarkophage, Munich, 1982; G. Koch, Frühchristliche Sarkophage, Munich, 2000; P. Zanker and B. Ewald, Living with Myths: The Imagery of Roman Sarcophagi, Oxford, 2012; M. Koortbojian, 'Roman sarcophagi’, in B. Borg, ed., A Companion to Roman Art, Chichester, 2015, 286-300. Recent edited volumes include J. Elsner and J. Huskinson, eds, Life, Death and Representation: Some New Work on Roman Sarcophagi, Berlin, 2011; J. Elsner and H. Wu, eds, Sarcophagi, special issue of RES: Anthropology and Aesthetics, 61/62, 2012 (including comparison with Chinese and MesoAmerican materials); M. Galinier and F. Baratte, eds, Iconographie funéraire romaine et societé, Perpignan, 2013. Some interesting recent methodological reflections: K. Lorenz, Ancient Mythological Images and Their Interpretation, Cambridge, 2016, 14-16, 71-88, 140-51, 210-23.

${ }^{4}$ See J. Elsner, 'Decorative imperatives between concealment and display: The form of sarcophagi', RES: Anthropology and Aesthetics, 61/62, 2012, 178-95, esp. 179-80.

${ }^{6}$ See J. Huskinson, Roman Children's Sarcophagi: Their Decoration and Its Social Significance, Oxford, 1996.

${ }^{7}$ A topic very poorly treated in the history of Sarkophagstudien partly because of the truly terrible archaeological history of most surviving 
examples excavated before the mid twentieth century. But important correctives have now been produced - especially K. Meinecke, Sarcophagum Posuit: Römische Steinsarkophage im Kontext, Wiesbaden, 2014, and B. Borg, Crisis and Ambition: Tombs and Burial Customs in Third-century CE Rome, Oxford, 2013, 213-40, which follow the important re-assessment of information on archaeological contexts for sarcophagi in J. Dresken-Weiland, Sarkophagbestattungen des 4.-6. Jahrhunderts im Westen des Römischen Reiches, Rome, 2003, esp. 98-149.

${ }^{8}$ E.g. Dresken-Weiland, Sarkophagbestattungen, 185-97; K. Meinecke, 'Invisible sarcophagi: Coffin and viewer in the Late Imperial age', in S. Birk and B. Poulsen, eds, Patrons and Viewers in Late Antiquity, Aarhus, 2012, 83-106; Borg, Crisis and Ambition, 229-35.

${ }^{9}$ See Borg, Crisis and Ambition, 214-29; Meinecke Sarcophagum Posuit, 34-43, 62-70.

${ }^{10}$ See Borg, Crisis and Ambition, 42-7, 213-14.

${ }^{11}$ E.g. the 'Tomba di Nerone' on the Via Cassia north of Rome, with E.

Thomas, ' "Nero's Tomb” and the crisis of the third century', RES:

Anthropology and Aesthetics, 61/62, 2012, 132-51, and Meinecke, Sarcophagum Posuit, 325-7.

${ }^{12}$ See S. Birk, 'Sarcophagi, self-representation and patronage in Rome and Tyre', in Birk and Poulsen, Patrons and Viewers in Late Antiquity, 107-34, esp. 119-30, although this exaggerates the 'privacy' of sarcophagi in Rome (e.g. 119: 'hidden in small and dark chamber tombs').

${ }^{13}$ One of the oddities in the literature is the divorce between studies of funerary portraiture and studies of portraiture on sarcophagi, as if the latter were not funerary portraits by definition. No sarcophagi figure in e.g. J. Mander, Portraits of Children on Roman Funerary Monuments, Cambridge, 2012.

${ }^{14}$ See the discussion of J. Huskinson, Roman Strigillated Sarcophagi, Oxford, 2015, 119-22. 
${ }^{15}$ See e.g. Z. Newby, 'In the guise of gods and heroes: Portrait heads on Roman mythological sarcophagi', in Elsner and Huskinson, Life, Death and Representation, 189-227.

${ }^{16}$ See R. Winkes, Clipeata imago, Bonn, 1969.

${ }^{17}$ For some thoughts on portraiture in sarcophagi, see K. Schauenberg, 'Porträts auf römische Sarkophagen’, in R. Stucky and I. Jucker, eds, Eikones: Studien zum griechischen und römischen Bildnis. Hans Jucker zum sechzigsten Geburtstag gewidmet, Bern, 1980, 153-60; Birk, 'Sarcophagi, self-representation and patronage’, 111-19; S. Birk, Depicting the Dead: Self-Representation and Commemoration on Roman Sarcophagi with Portraits, Aarhus, 2013.

${ }^{18}$ Birk, Depicting the Dead, is the most extensive discussion of these but in the context of all portraiture, not specifically medallions as a subcategory.

${ }^{19}$ See P. Arias, Camposanto monumentale di Pisa: le antichità, Pisa, 1977, no. A.2 est.; P. Kranz, Jahreszeiten-Sarkophage: Entwicklung und Ikonographie des Motivs der vier Jahreszeiten auf klassischen Sarkophagen und Sarkophagdeckeln, Berlin, 1984 (Die antiken Sarkophagreliefs, henceforth, ASR, 5.4), no. 44.

${ }^{20}$ For some discussion see J. Engemann, Untersuchungen zur Sepulkralsymbolik der späteren römischen Kaiserzeit, Münster, 1973, 35-9; F. Matz, Die Dionysischen Sarkophage, vol. 4, Berlin, 1975 (ASR IV.4), 452-66; Koch, Frühchristliche Sarkophage, 114-16; V. Platt, 'Framing the dead on Roman sarcophagi', RES: Anthropology and Aesthetics, 61/62, 2012, 213-27, esp. 225-7; Birk, Depicting the Dead, 47-9; Huskinson, Roman Strigillated Sarcophagi, 118-19, 129-30, 137; V. Platt, 'Framing the dead on Roman sarcophagi', in V. Platt and M. Squire, eds, The Frame in Classical Art: A Cultural History, Cambridge, 2017, 331-58, esp. 355-7.

${ }^{21}$ E.g. W. Wischmeyer, Die Tafeldeckel der christlichen Sarkophage konstantinischer Zeit in Rom: Studien zur Struktur, Ikonographie und Epigraphik, Rome, 1982, 59-69. 
${ }^{22}$ On centralization and symmetry in the 'landscape' form of the visual field see Elsner, ‘Decorative imperatives’, 188-94.

${ }^{23}$ Cf. M. Allen, 'Technique and message in Roman art', in Borg, $A$

Companion to Roman Art, 153-71, esp. 166-7 on optically distinct effects in the tooling of portraits to differentiate the interred from other figures in the visual field.

${ }^{24}$ See Koch and Sichtermann, Römische Sarkophage, 607-14; Newby, 'In the guise of gods and heroes'; Borg, Crisis and Ambition, 163-4; Birk, Depicting the Dead, 59-114.

${ }^{25}$ See Engemann, Untersuchungen zur Sepulkralsymbolik, 76-8; B. Andreae, 'Bossierte Porträts auf römischen Sarkophage - ein ungelöstes Problem', Marburger Winkelmann Programm, Marburg, 1984, 109-28; J. Huskinson, ‘"Unfinished portrait heads” on later Roman sarcophagi: Some new perspectives', Papers of the British School at Rome, 46, 1998, 129-58; B. Russell, The Economics of the Roman Stone Trade, Oxford, 2013, 301-7; Birk, Depicting the Dead, 55-8; Platt, 'Framing the dead' (2017), 356-7, discusses how both 'finished' and 'blank' portraits are presented as 'eternally incomplete', 'on the brink of three-dimensionality'. ${ }^{26}$ Portraits have typically been seen as reinforcing mythological subject matter - e.g. P. Blome, 'Funerärsymbolische Collagen auf mythologischen Sarkophagreliefs', Studi italiani di filologia classica, 10, 1992, 1062-73; M. Koortbojian, Myth, Meaning and Memory on Roman Sarcophagi, Berkeley, CA, 1995, 18; P. Zanker, 'Phädras Trauer und Hippolytos’ Bildung: Zu einem Sarkophag im Thermenmuseum', in F. De Angelis and S. Muth, eds, Im Spiegel des Mythos: Bilderwelt und Lebenswelt, Palilia 6, Wiesbaden, 1999, 131-42. For the current standard interpretation of such portraiture as 'exempla virtutis’, see Birk, Depicting the Dead, 59-114. Newby, 'In the guise of gods and heroes', complicates the interpretative blandness.

${ }^{27}$ For sarcophagi and visual rhetoric see J. Elsner, 'Image and rhetoric in early Christian sarcophagi’, in Elsner and Huskinson, Life, Death and 
Representation, 359-86; B. Borg, 'Rhetoric and art in third-century AD

Rome', in J. Elsner and M. Meyer, eds, Art and Rhetoric in Roman Culture, Cambridge, 2014, 235-55; Z. Newby, 'Poems in stone: Reading mythological sarcophagi through Statius' Consolations’, in Elsner and Meyer, Art and Rhetoric in Roman Culture, 256-87; J. Elsner, 'Rational, passionate and appetitive: The psychology of rhetoric and the transformation of visual culture from non-Christian to Christian sarcophagi in the Roman world', in Elsner and Meyer, Art and Rhetoric in Roman Culture, 316-49; Z. Newby, Greek Myths in Roman Art and Culture, Cambridge, 2016, 273-319. ${ }^{28}$ See esp. Newby, 'Poems in stone’; Elsner, ‘Rational, passionate and appetitive’, 318-28; Newby, Greek Myths in Roman Art and Culture, 27883.

${ }^{29}$ See M. Studer-Karlen, Verstorbenendarstellungen auf frühchristlichen Sarkophagen, Turnhout, 2012, who discusses these Christian 'portraits' at length.

${ }^{30}$ See B. Christern-Briesenick, Repertorium der christlich-antiken Sarkophage, vol. 3, Mainz, 2003, no. 40.

${ }^{31}$ As argued by Zanker and Ewald, Living with Myths, 163-73.

${ }^{32}$ For a list of examples found in Italy, see H. Wrede, 'Stadtrömische Klinensarkophage’, Marburger Winckelmann-Programm, Marburg, 1984, 105-8. For a catalogue of eighteen examples from Rome, see H. Wrede, 'Der Sarkophagdeckel eines Mädchens in Malibu und die frühen Klinensarkophage Roms, Athens und Kleinasiens', in M. True and G. Koch, eds, Roman Funerary Portraits in the J. Paul Getty Museum, vol. 1, Malibu, 1990, 15-46, esp. 36-41. For sarcophagi from Dokimeion in Phrygia in Asia Minor, see now V. M. Strocka, Dokimenische Säulensarkophage: Datierung und Deutung, Asia Minor Studien, 82, Bonn, 2017, 24-7.

${ }^{33}$ In fact it is not always easy to tell where a given example was made, especially if it is likely that different parts were manufactured in different places. See G. Koch, ‘Stadtrömisch oder östlich?’ Bonner Jahrbücher, 180, 
1980, 51-105, esp. 67-74 on the interesting example of a kline sarcophagus now in Norfolk, Virginia, whose lid Koch thinks is Attic but whose base he believes is a Roman copy of an Attic relief. For problems of discerning Attic from Asia Minor sarcophagi, see H. Wiegartz, ‘Attisch oder Kleinasiatisch: Bellerophon, Leda und Orpheus auf Attischen Sarkophagen und figürlichen Tischfigüren’, Vom Euphrat bis zum Bosporus: Kleinasien in der Antike : Festschrift für Elmar Schwertheim zum 65. Geburtstag, Asia Minor Studien, 65, vol. 2, Bonn, 2008, 725-34.

${ }^{34}$ On three-dimensional kline monuments and sarcophagus lids: L. Berczelly, 'A sepulchral monument from Via Portuense and the origin of the Roman biographical cycle', Acta ad archaeologiam et atrium historiam pertinentia, 8, 1978, 49-74; H. Wrede, 'Stadtrömische Monumente: Urnen und Sarkophage des Klinentypus in den beiden ersten Jahrhunderts n. Chr.', Archäologischer Anzeiger, 1977, 395-431; H. Wrede, 'Klinenprobleme’, Archäologischer Anzeiger, 1981, 86-131; Koch and Sichtermann, Römische Sarkophage, 58-61 (Italian), 371-3 (Attic), 505-6 (Asiatic); Wrede, 'Der Sarkophagdeckel eines Mädchens in Malibu’, 15-46; H. Goette, ‘Attische Klinen-Riefel-Sarkophage’, Athenische Mitteilungen, 106, 1991, 309-38; K. Dunbabin, The Roman Banquet, Cambridge, 2003, 110-14, 120-5; H. Wrede, 'Ein “Missing Link”: Zur Entstehung der römischen Klinensarkophage’, Pegasus, 10, 2008, 9-17; Borg, Crisis and Ambition, 200-2.

${ }^{35}$ See R. Lanciani, 'Dell scoperete avanute nei disterri del nuovo Palazzo di Giustizia', Bulletino della commissione archeological communlae di Roma, 17, 1889, 173-80; M. Bettini, The Portrait of the Lover, Berkeley, CA, 1999, 213-17; Meinecke, 'Invisible sarcophagi', 90-1; E. D’Ambra, 'Beauty and the Roman female portrait', in Elsner and Meyer, Art and Rhetoric in Roman Culture, 155-80, esp. 156-9.

${ }^{36}$ For example, see the late third or early fourth century Meleager sarcophagus in Rome, where the couple reclining have unfinished heads, the 
woman holds a musical instrument and the man a book scroll: G. Koch, Die mythologischen Sarkophage: Meleager, Berlin, 1975 (ASR XII. 6), no. 67, 102-3.

${ }^{37}$ See the group discussed in Wrede, 'Stadtrömische Monumente’, 417-21 (figs. 109-13).

${ }^{38}$ See A. Alexandridis, 'Death and the city: Asiatic columnar sarcophagi in context', in J. Osborne, ed., Approaching Monumentality in Archaeology, Albany, NY, 2014, 233-56, esp. 249.

${ }^{39}$ See E. Thomas, “"Houses of the dead?” Columnar sarcophagi as “microarchitecture”, in Elsner and Huskinson, Life, Death and Representation, Berlin, 2011, 387-435.

${ }^{40}$ See C. Reinsberg, Die Sarkophage mit den Darstellungen aus dem Menschenleben: Vita Romana Sarkophage, Berlin, 2006 (ASR I.3), no. 73, 212-14, also 30-2 and 107-9, with rich bibliography; more recently Borg, Crisis and Ambition, 87-8, 183-4.

${ }^{41}$ See H. Wrede, Senatorische Sarkophage Roms: Der Beitrag des Senatorenstandes zur römischen Kunst der hohen und späten Kaiserzeit, Mainz, 2001, no. 10, 121-2; Reinsberg, Die Sarkophage, no. 121, p. 227. One might cite also Reinsberg, Die Sarkophage, no. 41, p. 205 from c. 360, with very similar imagery to the Theodorus Sarcophagus but whose lid survives in very poor condition.

${ }^{42}$ See G. Lippold, Die Sculpturen des Vaticanischen Museums, vol. 3.2, Berlin, 1956, 116-20; M. Wegner, Die Musensarkophage, Berlin, 1966 (ASR 5.3), no. 139, p. 58; Huskinson, Roman Children's Sarcophagi, Oxford, 1996, no. 5.5, p. 39; B. Ewald, Der Philosoph als Leitbild: Ikonographische Untersuchungen an römischen Sarkophagreliefs, Mainz, 1999, no. D 5, p. 169.

${ }^{43}$ At least so Ewald, Der Philosoph als Leitbild, 169: Wegner, Die Musensarkophage, 58, says ‘toga’, while Huskinson, Roman Children’s Sarcophagi, 138 suggests “ “everyday” tunic’. 
${ }^{44}$ All published photographs show only four Muses to each side of the central figure. Lippold, Die Sculpturen des Vaticanischen Museums, 117-18, identifies these as Kalliope, Melpomene, Erato and Urania to the boy’s right hand side, and Polyhymnia, Thaleia, Euterpe and Terpsichore to his left (both groups listed from the centre). He places Klio on the extreme left of the base, almost at the back, 'behind' Urania.

${ }^{45}$ For some reflections on the gender issues see S. Sande, 'The female hunter and other examples of change of sex and gender on Roman sarcophagus reliefs', Acta ad archaeologiam et atrium historiam pertinentia, n.s. 22, 2009, 55-86, pp. 56-8.

${ }^{46}$ See Zanker and Ewald, Living with Myths, 199-244.

${ }^{47}$ See S. Rogge, Die Sarkophage Griechenlands und der Donauprovinzen: Die attischen Sarkophage. Achill und Hippolytos, Berlin, 1995 (ASR 9.1), no. 24, pp. 136-8, and L. Buccino in E. La Rocca and C. Parise Presicce, eds, Musei Capitolini: le sculture del Palazzo Nuovo, vol. 1, Rome, 2010, 350-77 (esp. 366-72 on the portraits).

${ }^{48}$ See A. Riegl, Spätrömische Kunstindustrie, Vienna, 1901, 74-5.

${ }^{49}$ See Koch, Die mythologischen Sarkophage, nos. 67 and 69, pp. 102-4 and pp. 16-24 for discussion of the group.

${ }^{50}$ See Matz, Die Dionysischen Sarkophage, no. 249, pp. 444-5; Kranz, Jahreszeiten-Sarkophage, no. 129, pp. 217-18.

${ }^{51}$ Dionysiac bliss: Zanker and Ewald, Living with Myths, 130-45.

${ }^{52}$ See H. Sichtermann and G. Koch, Griechische Mythen auf römischen Sarkophagen, Tubingen, 1975, no. 66, pp. 61-2; F. Baratte, 'Phaethon I', Lexicon iconographicum mythologiae classicae, VII.1, 1994, 350-4, no. 15, p. 352.

${ }^{53}$ See e.g. Zanker and Ewald, Living with Myths, 389-92 (in relation to a different Phaethon sarcophagus).

${ }^{54}$ For some discussion of this issue in relation to actual evidence of bones found, see Meinecke, Sarcophagum Posuit, 125-7 and the table on 374-7, 
but of course so many sarcophagi were reused or used over a long period for further interments that the empirical evidence is not easy to draw conclusions from. Nonetheless, for instance Meinecke’s B83, found in 2005/2006 with good context has two portraits but only one corpse.

${ }^{55}$ Notably from the sketchbook of Giovannantonio Dosio (1533-1611) now in Berlin: see C. Hülsen, Das Skizzenbuch des Giovannantonio Dosio im Staatlichen Kupferstichkabinett zu Berlin, Berlin, 1933, plate 22 (fol. 9r.).

${ }^{56}$ See C. Robert, Einzelmythen (ASR 3.1), Berlin, 1897, no. 86, pp. 107-8; H. Sichtermann, Die mythologischen Sarkophage, vol. 2, Apollon biz Grazien, Berlin, 1992 (ASR 12.2), no. 79, pp. 132-3; Wrede, 'Ein “Missing Link”, 14-15.

${ }^{57}$ See Sichtermann and Koch, Griechische Mythen auf römischen Sarkophagen, no. 68, pp. 63-4; H. Kaiser-Minn, Die Erschaffung des Menschen auf den spätantiken Monumenten des 3. und 4. Jahrhunderts, Münster, 1981, 46-7; Koch and Sichtermann, Römische Sarkophage, no. 215, 183-4; Zanker and Ewald, Living with Myths, 52-4.

${ }^{58}$ On Prometheus-creation sarcophagi, see Kaiser-Minn, Die Erschaffung des Menschen auf den spätantiken Monumenten, 32-55, and J. R. Gisler, 'Prometheus', LIMC, VII.1, 1994, 531-53, esp. 545-6.

${ }^{59}$ See H. Brandenburg, Atti del IX Congresso internazionale di archeologia Cristiana, vol. 1, Vatican, 1978, 462-70, esp. 466-7, and Kaiser-Minn, Die Erschaffung des Menschen auf den spätantiken Monumenten, 61-2.

${ }^{60}$ For a parallel salvific programme in a largely Christian funerary context, which focuses on Hercules bringing Alcestis back from Hades, one might cite Cubiculum $\mathrm{N}$ in the Via Latina Catacomb. See e.g. J. Elsner, Art and the Roman Viewer, Cambridge, 1995, 271-82.

${ }^{61}$ For a detailed account of struts in Roman art, see A. Anguissola, Supports in Roman Marble Sculpture: Workshop Practice and Modes of Viewing, Cambridge, 2018. 
${ }^{62}$ See K. Schauenberg. 'Die Lupa Romana als sepulkrales Motif', Jahrbuch des deutschen archäologischen Instituts, 81, 1966, 261-309, esp. 27-83; L. Berczelly, 'The soul after death: A new interpretation of the Fortunati sarcophagus', Acta ad archaeologiam et atrium historiam pertinentia, series altera, 6, 1987, 59-90, esp. 77-87; R. Amedick, Die Sarkophage mit Darstellungen aus dem Menschenleben: Vita privata, Berlin, 1991 (ASR I.4) no. 248, p. 161, also pp. 63 and 74-5; J. Stroszeck, Die dekorativen römischen Sarkophage: Die Löwen-Sarkophage. Die Sarkophage mit Löwenköpfen, schreitenden Löwen und Löwenkampfgruppen, Berlin, 1998 (ASR 6.1), no. 140, p.121; Birk, Depicting the Dead, no. 623.

${ }^{63}$ Berczelly, 'The soul after death', 64 and 81.

${ }^{64}$ See S. Birk, 'Man or woman? Cross-dressing and individuality on third century sarcophagi’, in Elsner and Huskinson, Life, Death and Representation, 229-60; Birk, Depicting the Dead, 115-84.

${ }^{65}$ See Birk, 'Man or woman?', 252-5, and Birk, Depicting the Dead, 175-80.

${ }^{66}$ A still more extreme case of gender ambivalence is a sarcophagus in the Museo Nazionale in Rome with a boy reclining in female dress, as here, and below the couch his nude form as corpse carved without facial features or genitals, as if in death indeterminacy is all. See Amedick, Die Sarkophage, no. 77, and Birk, Depicting the Dead, no. 620.

${ }^{67}$ See Amedick, Die Sarkophage, 72-6; Zanker and Ewald, Living with Myths, 59-62.

${ }^{68}$ For Meleager, see Koch, Die mythologischen Sarkophage, 38-47; R. Brilliant, Visual Narratives, Ithaca, NY, 1984, 151-4; K. Lorenz, 'Image in distress? The death of Meleager on Roman sarcophagi’, in Elsner and Huskinson, Life, Death and Representation, 309-36; Zanker and Ewald, Living with Myths, 62-6; Elsner, 'Decorative imperatives’, 189-90; Newby, 'Poems in stone', 256-87, esp. 271-3, 274-6; for Patroclus, see L. Giuliani, 'Achill-Sarkophage in Ost und West: Genese einer Ikonographie’, Jahrbuch 
der Berliner Museen, 31, 1989, 25-39, and Elsner, 'Rational, passionate and appetitive', 328-33.

${ }^{69}$ For some reflections on unfinishedness (not only heads) in Attic sarcophagi, see J. B. Ward-Perkins, 'The Hippolytus sarcophagus from Trinquetaille', Journal of Roman Studies, 46, 1956, 10-16, esp. 11-15. ${ }^{70}$ See Koch, Die mythologischen Sarkophage, no. 67, pp. 102-3. Russell, The Economics of the Roman Stone Trade, 301, perhaps rightly prefers 'blank portraits' to ‘unfinished heads'.

${ }^{71}$ See Kranz, Jahreszeiten-Sarkophage, no. 78, p. 207, and Wrede, ‘Der Sarkophagdeckel eines Mädchens in Malibu’, no. 6, pp. 38-9.

${ }^{72}$ See M. Chéhab, 'Sarcophages à reliefs de Tyr', Bulletin du musée de Beyrouth, 21, 1968, 1-84, no. 328, pp. 28-34, and Rogge, Die Sarkophage Griechenlands und der Donauprovinzen: Die attischen Sarkophage. Achill und Hippolytos, no. 42, pp. 143-4.

${ }^{73}$ See Chéhab, 'Sarcophages à reliefs de Tyr’, no. 907, pp. 61-7.

74 The inscription specifies that Aurelia wanted the coffin to hold her body alone and so it may be that the male head may have been left blank because there was to be no corresponding body. See for instance Strocka, Dokimenische Säulensarkophage, no. 61, pp. 221-2.

${ }^{75}$ See Strocka, Dokimenische Säulensarkophage, nos. 31, 145, and the lid from Hermione in the Argolis, illustrated at plate 97.1 and discussed at p. 28. ${ }^{76}$ See 'Acquisitions 1995’, The Getty Museum Journal, 24, 1996, no. 3, p. 88.

${ }^{77}$ See Ward-Perkins, ‘The Hippolytus sarcophagus from Trinquetaille’, 12; A. Giuliano, Il commercio dei sarcophagi attici, Rome, 1962, no. 232; A. Giuliano and B. Palma, La maniera ateniense di età romana: I maestri dei sarcophagi attici, Studi Miscellanei, 24, Rome, 1978, p. 39 ('maestro di Salonicca', no. 2).

${ }^{78}$ See M. Avi-Yonah, 'Recently discovered sarcophagi from Ashkelon’, Atiqot, 11, 1976, 72-6, esp. 72-4; G. Koch, 'Bemerkungen zu einen 
mythologischen Sarkophagen', Archäologische Anzeiger, 1979, 228-46, esp.

233-8; Koch and Sichtermann, Römische Sarkophage, 178.

${ }^{79}$ For example, take the piece briefly discussed by Ward-Perkins, 'The Hippolytus sarcophagus from Trinquetaille', 12, which is Giuliano, Il commercio dei sarcophagi attici, no. 331.

${ }^{80}$ See C. Picón, Art of the Classical World in the Metropolitan Museum of Art: Greece, Cyprus, Etruria, Rome, New York, 2007, no. 467, pp. 398, 497. The principal discussion is H. Wrede, 'Ein Sarkophagkasten mit zwei Deckeln’, Städel-Jahrbuch, 12, 1989, 29-40, esp. 30-1, 33-5 and 38.

${ }^{81}$ See Wrede, 'Ein Sarkophagkasten mit zwei Deckeln’, 29, fig. 1 and 31, fig. 3; Wrede, 'Der Sarkophagdeckel eines Mädchens in Malibu’, 24, fig. 16. Other examples are listed in Russell, The Economics of the Roman Stone Trade, 301 n. 171.

${ }^{82}$ It is often repeated - e.g. The Getty Museum Journal, 24, 1996, 88. A number of contributions that discuss and go beyond the earlier literature effectively hint at this. See Andreae, 'Bossierte Porträts auf römischen Sarkophage’, 125, wondering about unfinish as extreme abstraction in portraiture; Huskinson “"Unfinished portrait heads”', 149-52, on social conditions and the collective phenomenon, 152-4, on unfinish in relation to memory and mourning; B. Russell, "The Roman sarcophagus “industry”: A reconsideration', in Elsner and Huskinson, Life, Death and Representation, 119-47, esp. 138-41, points out how fully finished in every other respect many sarcophagi with 'unfinished’ heads are; Birk, Depicting the Dead, 558, argues that what she prefers to call 'blank portraits' 'obtained a meaning for viewers over time ... a social value'; Russell, The Economics of the Roman Stone Trade, 306-7, wonders about religious explanations and quotes a very interesting passage from Ulpian in the Digest (11.8.5): If a man’s remains have been buried in a monument which is said to be incomplete, nothing prevents it from being finished. But if the place has already become 
religious, the priests must establish how far the need to put the structure in proper shape can be met without offending against religion.

${ }^{83}$ Russell, The Economics of the Roman Stone Trade, 301-3, calculates $22.5 \%$ of recorded clipeus portraits (in a shield or roundel) and $43 \%$ of parapetasma portraits (in front of a curtain) are blank, although he does not lay out the data for these calculations. See also Birk, Depicting the Dead, 556 and 199, for large proportions.

${ }^{84}$ Russell, The Economics of the Roman Stone Trade, 303-4.

${ }^{85}$ On the numbers, we may estimate about $12,000-15,000$ examples (including fragments) survive from the second and third centuries CE, which give rough production totals of between 300,000 and 750,000 (depending on whether the survival rates are between $2 \%$ and $5 \%$ ). If the survival rate were much higher, say $20 \%$, then total numbers in this period would be $c .75,000$. For discussion, see G. Koch, Sarkophage der römischen Kaiserzeit, Darmstadt, 1993, and Russell, 'The Roman sarcophagus “industry”', 127-31. If we extend the period to include Christian sarcophagi to the end of the fourth century and numerous sarcophagus fragments from all periods, we may be looking at up to 20,000 survivals: see J. Elsner, 'Introduction’, in Elsner and Huskinson, Life, Death and Representation, 1-20, p. 1. ${ }^{86}$ With Birk, Depicting the Dead, 57 (her catalogue no. 626).

${ }^{87}$ Birk, Depicting the Dead, 55-8, does not quite say this but gets close.

${ }^{88}$ See S. Dillon, 'The portraits of a civic benefactor in second century Ephesus', Journal of Roman Archaeology, 9, 1996, 261-74; M. Pfanner, ‘Über das Herstellen von Porträts’, Jahrbuch des deutschen archäologischen Instituts, 104, 1989, 157-257, esp. 178-9; J. Trimble, 'Framing and social identity in Roman portrait statues', in Platt and Squire, The Frame in Classical Art, 296-330, esp. 314-6 on replication of heads. Further on the significance of the unfinished work in Roman antiquity, see Platt's discussion in this issue. 
${ }^{89}$ See Strocka, Dokimenische Säulensarkophage, no. 145 and plates 74.2, $76.1-2$.

90 Synge, Plays, Poems and Prose, 8. 